\title{
Jowita Żurawska-Chaszczewska
}

Państwowa Wyższa Szkoła Zawodowa w Gorzowie Wlkp.

\section{Stylistyczna funkcja barw w powieści Kollokacja Józefa Korzeniowskiego}

W powieści międzypowstaniowej modzie na cudzoziemszczyznę, próżności i zachłanności przeciwstawiano tradycyjny dwór szlachecki, w którym pielęgnowano dawne cnoty rodzinne i obywatelskie ${ }^{1}$. Piewcą staropolskich ideałów był Józef Korzeniowski - m.in. w powieści Kollokacja $(1847)^{2}$ wyszydzał szlacheckie zarozumialstwo i wysokie mniemanie o sobie posunięte aż do przesady, chciwość chwytającą się oszustwa, rujnujące resztki majątku zwyczaje biednej, drobnej szlachty ${ }^{3}$, pochwalał zaś stare porządki oparte na patriarchalnej rodzinie, w której żona jest oddana mężowi, dzieci posłuszne rodzicom, wszyscy zaś są pracowici i uczciwi, zadowalają się skromnym dostatkiem i nie szukają uciech i zbytków.

Tytułowa kollokacja ${ }^{4}$ (kolokacja) to ,wieś szlachecka podzielona na części należące do różnych właścicieli”s, zaś według Zygmunta Glogera:

Podług prawa polskiego wszelkie dobra dziedziców niewypłatnych, przeładowane długami, mogły ulec podziałowi pomiędzy wierzycieli [...]. Kolokacja oznaczała ubezpieczenie się kredytora w pierwszeństwie przed innymi do odzyskania należności z dóbr dłużnika. Jeżeli majątkiem odłużonym podzieleni zostali wierzyciele

${ }^{1}$ Por. H. Markiewicz, Pozytywizm, Warszawa 1980, s. 110.

2 J. Korzeniowski, Kollokacja, Kraków 2003. Dalej cytuję za tym wydaniem, w nawiasie podaję numer strony.

${ }^{3}$ Por. A. Witkowska, Literatura romantyzmu, Warszawa 1986, s. 271.

${ }^{4}$ Kollokacja 'umieszczenie, rozmieszczenie, rozklassyfikowanie wierzycieli, wyposażenie; majątek oddany im przez podział'. Słownik języka polskiego, wydany staraniem i kosztem M. Orgelbranda, t. 1, Wilno 1861, s. 509.

5 Słownikjęzyka polskiego, red. J. Karłowicz, A. Kryński, W. Niedźwiedzki, t. 2, Warszawa 1902, s. 403 (dalej: SW). 
i na jednym folwarku utworzyło się tym sposobem kilka dworów i folwarczków, to rozsiedlenie podobne nazywano także „kolokacją”.

Akcja powieści, która rozpoczyna się w 1838 roku, rozgrywa się w Czaplińcach, podzielonej wsi na Wołyniu, oraz w jej okolicy. Najważniejszym sąsiadem niezamożnej, wręcz ubogiej szlachty czaplinieckiej był prezes Zagartowski, który wszelkimi środkami starał się zagarnać rozdrobnione majątki dla siebie i tym samym powiększyć i tak już duże włości. Przez podstawionych Żydów pożyczał niefrasobliwym właścicielom skrawków Czapliniec ${ }^{7}$ duże sumy, a następnie przejmował ich długi i rugował szlachtę. Zabiegi te spełzły na niczym, gdyż jego machinacjom oparła się rodzina Starzyckich, która dzięki umiarowi wiodła spokojne i w miarę dostatnie życie.

W synu tej pełnej zalet familii zakochała się panna Kamila Zagartowska, która dla miłości odrzuciła względy wypieszczonego i sfrancuziałego arystokraty, a jako nieodrodna córka zaradnego prezesa zręczną intrygą doprowadziła do małżeństwa z Józefem Starzyckim.

Realizacji fabuły powieści służą barwy oddające nie tylko miejsce akcji, ale przede wszystkim wygląd i zachowanie bohaterów Kollokacji - przez precyzowanie ich sposobu ubierania się i uczuć. Jak zauważa Ryszard Tokarski, „bogata symbolika barw, a na poziomie językowym semantyczne konotacje ich nazw stanowią interesujące pole obserwacji znaczeniowych", dlatego też celem niniejszej pracy jest próba odpowiedzi na pytanie, jaką funkcję stylistyczną w kreowaniu rzeczywistości powieściowej Kollokacji pełnią barwy9

\section{Wygląd postaci}

Korzeniowski oszczędnie operuje barwami w kreowaniu świata przedstawionego powieści, gdyż zadaniem kolorów jest przede wszystkim indywidualizacja postaci, które jakaś szczególna cecha ma wyróżnić spośród drobnej szlachty, pełnej pretensji i pychy, żyjącej wystawnie, choć na kredyt, co w końcu prowadzi do utraty drobnych majątków. Przeciwstawiona zostaje im

${ }^{6}$ Z. Gloger, Encyklopedia staropolska, t. 3, Warszawa 1974, s. 59.

7 Zdaniem Stefana Kawyna: „Ta «rzeczpospolita kolokacyjna», ledwie wegetująca na mizernym swym gospodarstwie, brnąca mimo to lekkomyślnie w długi, wstrząsana anarchią rozbujałych temperamentów szlacheckich, intrygami i kłótniami, słaba i bezradna w istocie wobec drapieżności nienasyconego sąsiada - to środowisko poczciwych, ale głupich i krótkowzrocznych ludzi ukazane zostało w różnych postaciach komizmu, najczęściej groteski i satyry”. S. Kawyn, Wstęp, w: J. Korzeniowski, Kollokacja, Wrocław-Kraków 1958, s. CLVI.

${ }^{8}$ R. Tokarski, Semantyka barw we współczesnej polszczyźnie, Lublin 1995, s. 18.

9 Za Tokarskim traktuję barwę i kolor jako synonimy. Ibidem, s. 35. 
żyjąca tradycyjnie rodzina Starzyckich, którzy także w ubiorze hołdują zasadom skromności i porządku, stąd barwy przypisane im i ich otoczeniu mają waloryzować cnoty, podkreślać zalety i te cechy charakteru, które autor uznaje za najważniejsze.

1. Uroda. Do charakterystycznych cech postaci, starannie opisanych przez autora, należy aparycja, kreowana przez barwy twarzy, kolor oczu, włosów, a także rąk.

Biały. Nieskazitelna biel implikuje doskonałość, duchowość, czystość, jest „synonimicznie związana z dniem, aktywnością, klarownością wyraziście zorganizowanego świata" 10 , stąd w powieści Korzeniowskiego postaciom panien przypisana zostaje biel konotująca niewinność i dziewictwo ${ }^{11}$, waloryzująca ich cnoty $^{12}$, jak np. Anusi Starzyckiej, spokojnej, cichej, pełnej zalet narzeczonej, której biała postać wyróżnia się na tle ciemnego, nieoświetlonego domu w czasie spotkania z bratem: „Gdy pan Józef przechodził przez pierwszy pokój, postrzegł koło drzwi matczynych postać biała, która się do niego cicho zbliżała. Była to Anusia” (32), ale również panien Płachcianek: ,były to panienki lat dziewiętnastu i osiemnastu, tłuste, białe i nieszpetne” (37).

Urodę kobiet i mężczyzn w językowej kreacji powieści ilustruje biel ramion i rąk, które nie są wystawiane na promienie słońca, nie są zniszczone praca, co oddaje prawdziwą lub upragnioną zamożność bohaterów. Białe ramię ma niemłoda już, ale nadal zalotna pani Płachcina, biała raczke przypisuje autor pięknej Kamili, choć po matce Ormiance odziedziczyła ciemną skórę. Biała ręka wyróżnia również urodziwego i wykształconego Żyda Szlomę: ,Za jedwabny pas zasunąwszy wielkie palce trzymał w jednym ręku sobolową czapkę, a drugą wystawił jakby na pokaz, tak była biała i czysta" (19), podobnie jak oznaką jego powabów stają się zęby białe jak perty ${ }^{13}$.

Negatywnym elementem wyglądu jest papierowa twarz damy - czyli biała jak papier - skontrastowana z ciemną, ale zdrową cerą głównej bohaterki: „Nie miałaś nigdy rumieńców wypiętnowanych na papierowej twarzy, jak panna Hortensja; ale miałaś twarz świeżą, czerstwą i cerę śliczną" (48), co bliskie jest badaniom Tokarskiego:

Szczególnym przypadkiem odstępstw od semantycznej zależności między podstawową nazwą barwy a przyporządkowanymi jej nazwami niepodstawowymi jest

${ }^{10}$ P. Kowalski, Leksykon - znaki świata. Omen, przesą, znaczenie, Warszawa-Wrocław 1998, s. 225.

${ }^{11}$ Por. W. Kopaliński, Stownik symboli, Warszawa 1990, s. 22-23.

12 Por. E. Skorupska-Raczyńska, Kolorystyka dworu i zaścianka w „Nad Niemnem” Elizy Orzeszkowej, „Studia Językoznawcze” 2006, t. 5, s. 210.

${ }^{13}$ Co konotować ma ich doskonałość. Por. R. Tokarski, Semantyka barw..., s. 76. 
sytuacja, gdy na skutek znacznego, choć nie bezwyjątkowego ograniczenia łączliwości leksykalnej niektóre nazwy barw wytwarzają wtórne, nie związane wprost $\mathrm{z}$ referencją prototypową centra znaczeniowe. Tak jest w przymiotnikach kredowy bądź papierowy, które w funkcji określeń barwy, dość nieregularnie, choć naturalnie wtórnie łącząc się z rzeczownikami typu cera, twarz, policzki itp. sprzyjają rozwojowi konotacji 'choroby' czy 'śmierci'14.

Blada cera bowiem oddaje słabość i chorowitość, jak w przypadku Pożyczkowskiego: „Był to człowiek już niemłody, blady, chudy” (18) czy Henryka: „stanowiąc uderzający kontrast z bladym i znękanym panem Henrykiem” (75). Starość, a wraz z nią przychodzące choroby pozbawiają twarz zdrowych rumieńców, jak babcię Starzycką: ,Wieczorami grywał w mariasza z żoną, staruszką cokolwiek schorowana, już przygarbioną i blada, ale miłych rysów" (29), stąd nie dziwi pytanie panny Beldau łączącej bladą twarz z brakiem zdrowia: „Żart na stronę, Kamilciu, czy nie choraś ty doprawdy, boś pobladta" (48). Bladość, związana ze zmęczeniem, nie musi pojawiać się jedynie na twarzy: „owce beczały w wieczór, beczały w nocy i rano tak, że oczy pani Płachciny pobladty od bezsenności” (136).

Z kolorem białym łączy się epitet jasny, a także inne warianty tej podstawowej barwy achromatycznej, jak siwy i srebrny, w powieści widoczne w opisie koloru włosów bohaterów. Stały się one elementem waloryzacji cech postaci $^{15}$ : barwy jasne, kojarzone ze Słowianami, ilustrują postacie hołdujące tradycyjnym wartościom, staropolskim cnotom - jasna główka wyróżnia żonę Hipolita Starzyckiego, gęste i jasne włosy oraz wasy blond ma blondyn Józef Starzycki, którego - jako zadbanego mężczyznę, noszącego nakrycie głowy zdobi również czoło białe (,że tylko czoło jego wysokie było białe i jasne”, 48). Jego siostra Anusia określona zostaje przez autora jako ładna blondynka, tak samo jak żona Henryka Podziemskiego, dawnego adoratora Kamili, który - wzgardzony przez brunetkę - żeni się z młoda, ładna blondynka. Natomiast prezes Zagartowski, który jest postacią negatywną i swoim nieuczciwym postępowaniem przysparza cierpień innym ludziom, ma co prawda ,włosy jasne, ale nieczystego koloru" (16).

Biała głowa i wasy białe zdobią szanowanego seniora rodu Starzyckich („Niewielkie wąsy białe zakrywały wierzchnią wargę, 27), którego wiek precyzuje również użyte przez autora określenie włosy srebrne konotujące takie cechy, jak sprawiedliwość, radość, pokój, zwycięstwo, czystość, niewinność, czyste sumienie, wierność, szczęście ${ }^{16}$. Bohaterów mniej nobliwych, skłon-

\footnotetext{
14 Ibidem, s. 75.

15 Por. ibidem, s. 67-73.

16 W. Kopaliński, Słownik symboli, s. 400-402.
} 
nych hołdować uciechom wyróżniają zaś siwe włosy (Płachtę), siwa głowa (Pożyczkowskiego), czy przenośnie użyte czupryna przysypana szronem (Biruckiego). Na wiek wskazuje też was rudy i cokolwiek siwiejacy byłego żołnierza Siodłowskiego.

Włosy mogą lśnić i błyszczeć, ale w powieści cechy te mająjedynie czarne loki Kamili (,pan Józef [...] dumał o lśniacych lokach”, 47) i równie ciemne pejsy Żyda Szlomy (,rozum spekulacyjny zagnieździł się nie tylko pod takimi ładnymi lokami jak twoje, ale i pod takimi jak moje, choć mniej ładne i nie tak błyszcza", 51 - mówi Kamila do Żyda), co uwypukla ich doskonałość oraz powab i zdrowie.

Zalety głównej bohaterki, Kamili Zagartowskiej, która wyróżnia się urodą i cnotami, podkreśla otaczająca ją jasność: „Weszła na koniec panna Kamila, ubrana skromnie, ale jaśniejaca całą pięknością swojej wyniosłej postaci” (65), co kontrastuje z jej śniadą cerą i ciemnymi włosami, lecz jednocześnie oddaje jej skromność i elegancję: „nie miała na sobie żadnych ozdób, żadnych brylantów, jaśniała tylko poważną i dziwną pięknościq" (170).

Brązowy i jego odcienie. Na twarzy człowieka czas wypisuje historię życia - młodość to zdrowie, czerstwość, uroda, zaś z wiekiem lata ciężkiej pracy żłobią bruzdy, zostawiając ślady przeżyć i wydarzeń. Kolor cery jest w powieści symbolem piękna, zdrowia, ale też wskazówką zajęć i stanu majątkowego, gdyż jako ogorzaty od słońca, mający ogorzała twarz przedstawiony zostaje Józef Starzycki, młody, ale stateczny spadkobierca tradycji prawej rodziny, który ciężko pracuje, by utrzymać mająteczek matki w dobrym stanie. Twarz troche śniada, pteć cokolwiek śniada ${ }^{17}$ ma Kamila, która odziedziczyła ją po pięknej matce obcego pochodzenia: „Żona jego [prezesa - J.Ż.Ch.], po której wziął znaczny posag, pochodziła z dawnych ormiańskich familii osiedlonych koło Kamieńca i w Galicji, na Pokuciu. Była to kobieta żywa, ładna, wysoka i mocno śniada" (16).

Czerwony. Czerwień wiąże się z witalnością i prokreacją, symbolizuje namiętność i zmysłowość ${ }^{18}$, intuicyjnie zaś kojarzy się z pięknem, młodością, żywotnością ${ }^{19}$, stąd dowodem zdrowego trybu życia Henryka Podziemskiego stają się barwy na jego twarzy: ,ustawiczne prawie przebywanie na dworze umacnia jego zdrowie, wprowadza rumieniec na jego twarz" (98). Dobrym zdrowiem cieszy się też Płachcina, której ,na rozległym [...] gorsie zwijał się w przezroczystą mgłę stary, pożółkły szalik gazowy okręcony dwa razy i zdawał się reprezentować obłok, na którym malowały się żywe kolory tej korpulentnej Irydy" (39).

${ }_{17}$ Miała więc ciemna, jasnobrązową cerę. Por. R. Tokarski, Semantyka barw..., s. 201.

${ }_{18}$ P. Kowalski, op.cit., s. 229-300.

19 R. Tokarski, Semantyka barw..., s. 96-97. 
Pejoratywnie rumiana twarz i iskrzqce oczy są sygnałem dobrego samopoczucia związanego z nadużywaniem trunków: „Po śniadaniu wszyscy z rumianq twarzq i iskrzqcymi oczami pożegnali jaśnie wielmożnego dobroczyńcę" (136), podobnie jak nos zaczerwieniony wyróżnia szlachcica Biruckiego, który nie stronił od alkoholu, jako że „bał się dwóch rzeczy: próżnej butelki i żony" (40).

Objawami choroby staje się natomiast intensywna czerwień jako barwa twarzy: twarz okropnie czerwona, twarz purpurowa od krwi ilustruje groźną chorobę prezesa Zagartowskiego, która prowadzi do zgonu: „Dobrze, dobrze, posyłaj - odpowiedział prezes, wstrząsnąwszy się na te słowa i zwracając na Żyda twarz okropnie czerwona i wytrzeszczone oczy" (159).

Stereotypowo czerwień ${ }^{20}$ jako barwa doskonała przypisana zostaje powabnym ustom („nawet usta twoje pobladły, co były zawsze jak korale”, 48), czy mniej poetycko określonym jako rumiane, z kolei zdrowie i siłę ilustrują w powieści usta jeszcze rumiane seniora Starzyckiego.

Czerwone ręce natomiast oddają niski status ich właścicielek, które muszą nimi pracować i nie mogą ich cały czas chronić rękawiczkami, jak Pożyczkowska („Była to kobieta wysoka, pleczysta, dosyć ciała mająca z ogromnymi i czerwonymi rękami", 24).

Czarny. Czerń w opisie postaci łączy się z pięknością i młodością, z temperamentem, ale również z brzydotą i chorobą.

Bohaterów wyróżnia barwa włosów, wskazując na ich pochodzenie i wiek. Kamila to „kompletnie piękna brunetka” (16) ma czarne wlosy, czarne loki, które lśniq jak krucze skrzydła, ilustrując również jej żywy temperament. Włosy poczernione ma próżna i groteskowa Płachcina, która próbuje naśladować arystokrację widzianą za młodu: „Wyszła wreszcie solenizantka w berecie na włosach poczernionych, o które brukały się jeszcze bardziej brudne już białe pióra [jej beretu - J.Ż.Ch.]" (39). Owa fałszywa, sztuczna czerń włosów oddaje niemłody wiek, jak również dowodzi niechlujstwa szlachcianki.

Urodę postaci ilustrują czarne oczy, ciemne oczy, a mają je Kamila, Henryk Podziemski i Żyd Szloma (,,pan Józef [...] dumał [...] o czarnych, ślicznych oczach, które tak głęboko zajrzały do jego duszy", 47), Józefa zaś czynią powabnym brwi ciemniejsze oraz rzęsy jeszcze ciemniejsze.

Zupełnie popsute i czarne zęby ma natomiast nieurodziwa, pełna pretensji guwernantka Francuzka (,a panna Beldau patrząc na przystojnego młodzieńca, także nie wiedzieć dlaczego, zaśmiała się i pokazała $d w a$ rzędy zębów, $z$ których połowy nie było, a druga była czarna $i$ wykruszona", 10), co oddaje

${ }^{20}$ Zdaniem Tokarskiego „w ogóle potoczne wyobrażania utrwalone w języku zdają się traktować czerwień, zwłaszcza ust i twarzy, jako oznakę siły i zdrowia”. Ibidem, s. 97. 
jej szpetotę, zły stan zdrowia i niemłody już wiek. Epitet czarny w określeniu rąk pojawia się jednostkowo, ilustrując brud, gdyż ma je służący Ignacy, całe uwalane błotem, kiedy próbuje wydobyć kocz z błota, zaś klęska Henryka, który na oczach ukochanej spada z konia, staje się tym dotkliwsza, że ma on zabłoconq twarz.

Inne. Pozostałe nazwy barw pojawiają się przede wszystkim w ilustracji kolorów oczu, jak powiązany z bielą i szarością przymiotnik siwy ${ }^{21}$, czy też z niebieskim - błękitny i ciemnobłękitny. Bohaterowie wywodzący się z tradycyjnego domu, poza włosami blond, mają też błękitne oczy, niebieskie oczy, jak Anusia i Józef, choć o tym ostatnim pisze autor niekonsekwentnie, że ma oczy ciemnobtękitne. Siwe oczy należą do pana Jakuba i dziadzia Starzyckiego, a także pani Pożyczkowskiej i prezesa, który ,,przymrużał siwe oczy, bystre i przenikliwe" (16).

Oznaką śmierci prezesa stała się sina ${ }^{22}$ barwa twarzy: „Znaleziono prezesa na ziemi, z sinq twarzq i bez życia” (160), jako że ,zabarwienia ciała związane z urazami, chorobą odwoływać się będą do właściwych nazwie niebieski konotacji śmierci, które najpełniej realizowane są w semantycznie przyporządkowanych niebieskiej niepodstawowych nazwach barw typu siny, śliwkowy, granatowy"23.

Jednostkowo użyty zostaje przymiotnik wyzłocony, który ma przeciwstawić skromnej, choć bogatej prezesównie próżną, brzydką guwernantkę pannę Beldau, która stara się podkreślić swoją urodę przeładowanym, tandetnym, nadmiernie strojnym ubiorem: ,pokazała się panna Beldau, wystrojona, wyzłocona, wyłańcuszkowana" (66). Złoto nie konotuje tu doskonałości ${ }^{24}$, ale nadmierny przepych i brak dobrego smaku.

2. Ubiór. Barwne stroje przypisane zostają drobnej, kolokowanej szlachcie, ilustrując jej zły gust idący w parze z próżnością, natomiast w opisach ubiorów stawianej za wzór rodziny Starzyckich i zamożnych rodzin Zagartowskich i Podziemskich nie odnajdujemy wielu barw. Dominująca pozostaje czerń.

Czarny. W językowej kreacji postaci Kamili Zagartowskiej nazwy barwy strojów pojawiają się dopiero wtedy, kiedy straciwszy ojca, młoda kobie-

${ }^{21}$ Por. ibidem, s. 68.

${ }^{22}$ „W polszczyźnie występuje stale tylko w ograniczonym znaczeniu jako określenie koloru sinego (czyli niebieskiego z lekką domieszką czerni) ciała". A. Zaręba, Nazwy barw w dialektach i historii języka polskiego, Wrocław 1954, s. 43.

${ }^{23}$ R. Tokarski, Semantyka barw..., s. 145.

${ }^{24}$ „Złoty kolor w potocznym doświadczeniu językowym funkcjonuje jako synonim bogactwa. Podobnie rzecz się ma w tradycji ludowej, w której mówiąc o powodzeniu bohaterów, o wystroju pałacu itd. często używa się barwy złotej (lub żółtej)”. P. Kolwalski, op.cit., s. 227. 
ta chodzi $w$ żałobie, co konotuje czerń, a więc smutek, żal, stratę, śmierć ${ }^{25}$, której widocznym elementem jest czarna suknia ${ }^{26}$ („panna Kamila w czarnej jeszcze sukni [...] rzuciła się w jego [dziadka Starzyckiego - J.Ż.Ch.] objęcie i zaczęła ręce jego całować", 168), czarno ubiera się też Józef, idąc na spotkanie z ukochaną: „na cmentarzu parafialnego kościółka stał oparty o kratę grobowca mężczyzna czarno ubrany i patrzył na pływający na niebie księżyc" (169). Z kolei dziadek Starzycki nosi ,kurtkę manszestrową ${ }^{27}$ czarna, sukienną kamizelkę" (27), czapliniecki elegant pan Jakub - czarny frak dawnego kroju, podobnie ubrany - bo w czarny kaftan - jest majętny Szloma.

Biały. Z kolei białą suknię zakłada bohaterka na swój ślub (,wyszła panna Kamila w białej sukni, z mirtem na głowie i z woalem", 169-170) jako oddającą czystość jej serca i ciała.

Biel pojawia się także w określeniach części strojów innych osób. Czepek biały nosi na głowie pani Pożyczkowska, a jej mąż kamizelkę biała i brudna, co oddaje ich ubóstwo, jak również niedbalstwo, podobnie jak w przypadku Płachciny, która swój beret ozdobiła białymi piórami, powalanymi od jej poczernionych włosów, inaczej niż u Starzyckich, u których można znaleźć czystą bieliznę. Biały halsztuk zdobi Płachtę, a białe chusteczki na szyi noszą panny Płachcianki i pan Jakub, elegant umizgający się do ich matki (,biała chustka na szyi, na ogromnej rogówce grubo i dosyć wolno okręcona, szła pod same uszy", 43), zaś szlachcic Birucki ma biały kapelusz.

Szary. Skromny ubiór wyróżnia rodzinę Starzyckich: Hipolit, ojciec Józefa, zakłada do pracy szara czamarkę z czarnymi potrzebami i ,chodził zawsze w jasnym sieraczkowym surducie" (31), zaś elementem charakterystycznym dla nestora rodu Starzyckich jest popielata czapeczka, niekonsekwentnie nazywana przez autora także jasnopopielata (,Miał [...] na głowie jasnopopielata zajęczą czapeczke, miękką i ciepłą”, 27).

Inne. Barwne stroje zakłada drobna szlachta, jak rodzina Płachtów, której głowa rodu pokazała się na imieninach żony ubrana w cynamonowy frak i granatowe ciasne szarawarki, jego małżonka natomiast założyła pożółkły szalik gazowy oraz beret z piórami, choć „,czas pokryt szacowna niepewnościa kolor materii, z jakiej był zrobiony" (37), ich córki - panny Płachcianki występowały w niebieskich i różowych trzewiczkach, w perkalach ogromnych

${ }^{25}$ R. Tokarski, Semantyka barw..., s. 49.

${ }^{26}$ „Przejęty od starożytnych Egipcjan obyczaj zaczerniania twarzy przez krewnych zmarłego, wywodzący się - jak pisze W. Kopaliński - z chęci ukrycia tożsamości żywych przed zawistną duszą nieboszczyka, przeniesiony na kolor stroju żałobnego i dekoracyjnych elementów obrzędu pogrzebowego stał się zewnętrznym wyrazem emocjonalnej postawy wobec śmierci i zmarłego". Ibidem.

${ }^{27}$ Manszestrowy 'półaksamitny', SW, t. 2, s. 876. 
z fermoarem ${ }^{28}$ ciężko brazowym oraz „w kwiatkach, na których kurzawa legła grubą warstwą i dawała różom i makom kolor cegły, a powojowi błękit paznokci w febrze" (38). Arystokratyczne pretensje i niechlujstwo małżonków ilustruje określenie zszarzana komilfowośc $c^{29}$ : „W toalecie państwa Płachtów i panien Płachcianek był ten sam charakter zdartej i zszarzanej komilfowości" (37), a także brudnożótty pasek ,na kołnierzu, który miał reprezentować galon" (38), zaś ich rozrzutność - kupiony od podstawionego Żyda na kredyt galon szczerozłoty, który „zajaśniat na kołnierzu Żorża” (93).

Także mniej majętni właściciele części podzielonych Czapliniec nie stronili od kolorowego stroju, ich zdaniem wystawnego, choć - przez częste używanie - już wyszarzałego i zaniedbanego. Pożyczkowski miał nankinowe $e^{30}$ spodnie, spod których wystawały cholewy niepoczernione i rude, Birucka nosiła suknię zielonego podobno koloru i ,wielki szal pomarańczowy, który, chociaż był trzy razy okręcony na jej ręku, jeszcze jednak wlókł się po ziemi” (40), a po otrzymaniu kredytu ,sprawiła sobie zielonq atłasową sukniq do pomarańczowego szalu" (93). Bracia Smyczkowscy ubierali się w granatowe czamarki, występowali ,jeden ze skrzypką w ręku, obwiniętą czerwonq chustka do nosa, drugi z klarnetem, okręconym także chustka i także czerwonq" (42), natomiast pan Jakub nosił szarawarki jasnomigdałowego koloru i paliowa ${ }^{31}$ kamizelkę.

Odmiennie zamożność Szlomy oddają buty równie wyglansowane, lśnique.

\section{Uczucia bohaterów}

W językowej kreacji postaci barwy egzemplifikują pozytywne lub negatywne przeżycia, np. pana Józefa, gdy mieni się ${ }^{32}$ na twarzy co chwilę, kiedy spotyka prezesa, ojca ukochanej, lub kiedy - domyśliwszy się celu wizyty związanego z Kamilą - „w oczach [mu] się zaćmito” (57). Z kolei głębokie zawstydzenie sprawia, że Henryk Podziemski w towarzystwie Kamili, „blednac i czerwieniqc się na przemian słuchał jej ze spuszczonymi oczyma" (74), natomiast blask lustr rozlewa się po twarzy pani Płachciny w chwili szczęścia.

${ }^{28}$ Fermoar 'zameczek, zapinka, klamerka u naszyjników, paciorków, łańcuszków', SW, t. 1, s. 733 .

${ }^{29}$ Komilfowość 'wytworność, elegancja, szyk'; z franc. comme il faut 'jak należy', SW, t. 2, s. 419.

${ }^{30}$ Nankinowy 'z nankinu; z chińskiej tkaniny bawełnianej, żółtawo-czerwonej'. Za: przypis w J. Korzeniowski, Spekulant, Kollokacja, w: Dzieła wybrane, t. 1, Kraków 1954, s. 421.

${ }^{31}$ Paliowy 'słomkowy, koloru słomkowego', SW, t. 4, s. 21.

${ }^{32}$ Mieni się na twarzy od gniewu, wstydu, zachwytu 'stawać się to bladym, to czerwonym, to sinym', SW, t. 2, s. 957. 
Rumieniec. W ważnych chwilach życia towarzyszy bohaterom rumieniec - zdradza ich żywe zainteresowanie, gorące uczucia: Józef czerwieni się, opowiadając Kamili o swoim z nią sąsiedztwie, czerwieni się, kiedy wyjawia siostrze tajemnicę swego serca, a także pod bystrym spojrzeniem ojca: ,,- Ty? odpowiedział ojciec spojrzawszy bystro na syna, który się zaczerwienit" (57); Kamili lice płonie, żywy rumieniec okrywa twarz podczas pierwszego spotkania z ukochanym, zarumieniona twarz zdradza jej zainteresowanie młodzieńcem, kiedy jego pies ,położył głowę na jej kolanach, a [ona] wdzięczna [...], objąwszy ją obiema rączkami, przyłożyła do niej zarumieniona twarz" (14). Jednocześnie piękność zakochanej dziewczyny oddaje porównanie przywołujące różę jako królową kwiatów, konotującą piękno, wiosnę, młodość, miłość ${ }^{33}$ : „Zaczerwieniła się jak róża panna Kamila” (11).

Także inni bohaterzy, których dosięgła strzała Amora, czerwienią się pod wpływem spojrzeń ukochanych czy na samą myśl o nich. Rumienienie się staje się sygnałem odwzajemnionych uczuć, których nie można wyjawić słowami, jak w przypadku Anulki Starzyckiej, która właśnie dzięki niemu rozpoznała zainteresowanie adoratora: „Bawił pół dnia i wkrótce postrzegłam, że na mnie poglądał i czerwienił się” (32); „Jakem mu po obiedzie podawała kawę, samam zaczerwieniła się, nie wiedzieć czego" (32). Anulka czerwieni się też jednak w czasie spotkania z prezesem, co oddaje jej skromność, autor zaś ilustruje zawstydzenie młodej dziewczyny zbanalizowanym porównaniem do pięknego kwiatu: „- A ty zaczerwieniłaś się? - Okropnie, jak piwonia, aż mi wstyd było" (32).

Henryk Podziemski rumieńcem zdradza siłę swych uczuć: „Oko jego ożywiło się, lice okrył delikatny rumieniec" (66), ale czerwieni się też w sytuacjach dla niego niezręcznych - kiedy matka zwraca mu uwagę: ,i poszła [jego matka], nie zważając, jak zadrżał młody człowiek, jak się zaczerwienit i zmięszał" (67); zaś panny Płachcianki okrywają się rumieńcem na widok kawalerów: „Zaczerwieniły się panienki obaczywszy panów Smyczkowskich i krzyknęły obie" (166). Wspomnienia rumieńców towarzyszących miłości ma też dziadek Starzycki: „Ja uśmiechnąłem się i zaczerwieniłem, a ona mi na to: «Aha, wiem, nie ma złej drogi do swojej niebogi. No, jedź wasan, jedź»» (80).

Rumieniec ilustruje wrażliwość i delikatność uczuć: „Ale panna Kamila podeszła do niej prędko i śmiało, wzięła jej obie ręce i rzekła ciszej: - My się już znamy. Zaczerwieniła się na te słowa młoda kobieta i łzy zakręciły się w jej oczach" (82).

Zawstydzenie, zaskoczenie i zdziwienie powiązane z pomieszaniem także powodują zaczerwienienie się, jak w przypadku opanowanego zwykle Szlo-

${ }^{33}$ W. Kopaliński, Stownik symboli, s. 361-364; idem, Stownik mitów i tradycji kultury, Warszawa 1987, s. 1001-1002. 
my, którego zdradza rumieniec, kiedy Kamila wyjaśnia mu, że domyśla się ojcowych planów wzbogacenia: „Zaczerwienit się cokolwiek Żyd, a potem patrząc jej bystro w oczy, jakby chciał przeniknąć, do czego te słowa zmierzają, dodał [...]" (50). Matka Henryka czerwieni się od niecierpliwości, Józef z radości, jego ojciec oburzony (,-- Kto to mówił, to kłamał - rzekł [Hipolit - J.Ż.Ch.], czerwieniqc się cokolwiek, zacny człowiek, oburzony widokiem takiej hipokryzji”, 150), prezes złapany na matactwach, a Skrętski z gniewu (,Zaczerwieniła się znowu twarz pana Srętskiego, ale już nie ową skromnością oczekiwanego wyboru, lecz gniewem", 139). Kiedy Kamila uznała, że udało się jej naprawić większość krzywd wyrządzonych przez ojca, ,rumieniec zaczął na jej twarz powracać" (166). Stopień zmiany barwy twarzy, a więc i siłę uczuć precyzują epitety silny, lekki, delikatny i żywy.

Gniew, rozpacz ilustrują barwy konotujące związek z czerwienią i płomieniem, jak oczy pałajace ogniem (,Twarz jego była blada, wargi zaciśnięte, oczy pałały jakimściś nienaturalnym ogniem, a całe ciało drżało jak w febrze", 112).

Z kolei barwa żółta pojawia się jako ilustracja stanu złośnicy Biruckiej,

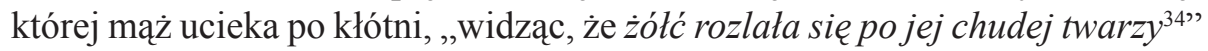
(134).

Bladośćc ${ }^{35}$. Przeciwieństwem rumieńca jest bladość, która towarzyszy bohaterom w chwilach zdenerwowania, niepewności, jak również kiedy odczuwają nienawiść i złość ${ }^{36}$. W powieści idzie w parze z uczuciem miłości, a nieszczęśliwie zakochani lub napotykający jakieś przeszkody marnieja, czego odzwierciedleniem ma być blade oblicze, jak w przypadku Józefa, który z miłości ,zesmutniał, zmizerniał i pobladt” (56), „Wkrótce wszedł pan Józef bledszy i mizerniejszy, niż był przed trzema tygodniami” (74-75). Szczęśliwa miłość także pozbawia rumieńców: Józef, „gdy się dowiedział, że kochany tak silnie, tak gorąco kochany, zbladł jak trup, upadł na krzesło" (84); zakochanej Kamili twarz pobladła, nawet usta pobladły, zbladła jak ściana, zbladła jak trup: ,pod koniec panna Kamila wstrząsnęła się, zbladła jak trup i gdy skończyła, opuściła ręce wraz z listem, zachwiała się i upadła na ziemię bez zmysłów” (119); zawiedziony i nieszczęśliwy Henryk „oparty o fortepian, z twarza jak trup blada, stał [...] odwrócony od gadatliwej Francuzicy i patrzał z natę-

34 „Natomiast w języku ogólnym wyraźnie nazwa barwy żółty kojarzona jest w negatywnymi stanami emocjonalnymi lub chorobowymi, por. żółty ze złości, zazdrości, żółta twarz, cera”. R. Tokarski, Semantyka barw..., s. 128.

35 Blady 'białawy, cery albo barwy zbliżającej się do białej', SW, t. 1, s. 161.

36 Por. E. Skorupska-Raczyńska, ,...na wzgórza libijskie padł złowrogi cień”. O funkcji barw w językowej kreacji starożytnego świata w „,Faraonie” Bolesława Prusa, ,Studia Językoznawcze" 2007, t. 6, s. 145. 
żeniem na pannę Kamilę" (72). Ten stan zwraca uwagę innych, np. pani Podziemskiej, której zdradza tajemnicę serca jedynaka: „Biedna kobieta znękana rozmową z chytrym i twardym zdobywca, przestraszona bladościq swojego jedynaka, spojrzała podejrzliwie i dumnie na pannę Kamilę" (77).

Blady odchodzi z domu prezesa Pożyczkowski po stracie swojego mająteczku: „Powstał szlachcic jeszcze bledszy, niż byt dotad, ukłonił się nie odejmując rąk od ciała i wysunął się cofając się tyłem do drzwi” (24). Upokorzona przez prezesa pani Włodzimierzowa, matka Henryka, ,nareszcie otarła oczy, podniosła bladq twarz" (71), przerażony zabawą z psem Henryk ,zaczął go z wolna głaskać. Ale ręka jego drżała i twarz widocznie pobladta" (78), co zdradziło jego tchórzostwo, podobnie jak jego zachowanie podczas pojedynku, po którym był blady jak z grobu oraz ,pobladt jak ściana i oddawszy strzelbę zakrył sobie twarz ze wstydu i uciekł nazad do domu” (97); ,jak mi to panisko pobladło i trzęsie się jak osika" (98). Wreszcie młody człowiek postanowił wydostać się spod skrzydeł matki i stąd ,wzrok jego był zupełnie zmieniony, włosy w nieporządku, czoło i lice nie okazywało najmniejszego śladu krwi" (115).

Blask i mgla. Oczy iskrzqce się mogą ilustrować złość, zdenerwowanie, jak w zachowaniu arystokraty: „pan Henryk szedł prędzej, z twarzą coraz bledszą, z zaciśniętymi wargami, z oczami coraz mocniej iskrzacymi" (113); radość i zadowolenie, jak oczy Szlomy, kiedy zobaczył piękne klejnoty ofiarowane jego córce Racheli przez Kamilę; determinację i gniew, kiedy Kamila mówiła ojcu o swojej miłości: „Przy tych słowach zaiskrzyly się oczy panny Kamili” (127); wściekłość, gdy Birucka kłóciła się z mężem. Oczy mogą świecić, waloryzując cechy charakteru, np. konotując mądrość (,,co spostrzegłszy Żyd, uśmiechnął się także, zaświecit czarnymi oczami petnymi rozumu”, 49), grzeczność („Oczy jego czarne, osłonione długimi rzęsami, jaśniały uprzejmościq”, 18), mogą też przywoływać wyidealizowany obraz ukochanej: Józefowi „wyobraziły się czarne oczy, ciemne oczy blysnęły przed jego dusza" (32).

Żywe spojrzenie kontrastuje z przymglonymi oczami znudzonego i nieszczęśliwego Henryka, który wychowywany przez nadopiekuńczą matkę romansuje i czyta romanse, wszystkiego się boi, a złe wychowanie nazywa okresem, „kiedy oczy moje zakrywała mgla” (118), dopiero bowiem kiedy spotka pannę, która zawróci mu w głowie, jej słówko sprawi, że jego oczy zajaśnieja. Także Szloma podczas rozmowy z Kamilą po śmierci jej ojca „stał wyprostowany, patrzył na nią z zajęciem i oczy jego przymglone nie blyszczały jak zwykle" (161).

Śladem żalu staje się błysk łzy: Anusia ,rzekła patrząc w te śliczne czarne oczy, w których tza jak brylant błysnęta" (83), natomiast mrok i cień pojawiają się w oczach bohaterów, kiedy spotyka ich coś ważnego - Józefowi ćmi się w oczach, gdy żegna swą ukochaną na zawsze. 


\section{Otoczenie}

Barwy. Wieś Czaplińce nie mieni się barwami, autor wspomina jedynie o dymie sygnalizującym obecność gospodarzy: „,nade wszystko zastanowił ją dym wychodzący jasnym stupem z komina jednego z najposażniejszych dworków” (8); „Im wyżej podnosił się ów biały słup w powietrze, tym przezroczystszym się stawał, tym rozmaitsze przybierał formy, a przyjmując w siebie żywe promienie jesiennego słońca, rozlicznymi ozdabiał się kolorami” (8-9), choć ,we wsiach wszystkie płoty były obryzgane, wszystkie karczmy wygladaty pstrokato" (5).

W okolicy wyróżnia się zadbany dworek szlachecki rodziny Starzyckich, gdyż owo mieszkanie ,w samym środku wsi położone oznaczało się od innych dworków porządkiem, czystością, obszernością i miłym widokiem dostatku" (26), co podkreśla biała barwa ścian siedziby: „Równolegle do ulicy, w głębi podwórza stał dom właściciela, niewysoki, niezbyt wielki, pod dachem słomianym, ale ściany jego byty białe, okna o sześciu szybach czyste i całe, a na samym środku był ganek obszerny, nakryty, wyheblowany" (27). Dach słomiany przywodzi na myśl kolor żółty konotujący bogactwo, w tym wypadku zaś dostatek. Z jasną bryłą budynku harmonizuje zieleń drzew ocieniających rodową siedzibę - miała ona ,z obu stron [...] dwa wielkie klony, których szerokie liście dawały latem chłód, cień i zielonymi kitami zaglądały do ganka" (27). Zieleń jako kolor nadziei, radości i bogactwa ${ }^{37}$ waloryzuje dom Starzyckich, podobnie jak jasne okna, ,z których wyglądał pokój, umiarkowanie i owa wyższość, jaką daje rozum, sumienie i wiara" (156).

Wnętrze urządzone zostało tak, aby zapewnić wygodę mieszkańcom, ale też by nie musiało być co chwilę zmieniane - Starzyccy zadbali, by sprzęty były niezbyt modne, lecz za to schludne i czyste: „meble z jesionu obite płócienkiem szarym, wyszytym czerwonymi i czarnymi sznureczkami; nigdzie nic modnego, ale ani starego i obszarpanego, wszystko na równi ze stanem odpowiadało możności, wygodzie i istotnej potrzebie" (27).

Jakże inaczej oczom gości przedstawiał się dom Płachty, gdzie „dach był na domu dziurawy, ściany obszarpane, okna w większej części zaklejone papierem, stodoła i obory w ruinach" (37). Niedbalstwo widoczne było również w urządzeniu pokoi: „Umeblowanie domu odpowiadało reszcie: zszarzana elegancja, popaczone mahoniowe forniry, dziurawe i wystrzępione obicia, stare i nawet nie połatane dywaniki itd." (38).

Barwy jednostkowo pojawiają się w nazwach powozów i uprzęży, np.: „Zajechała żółta bryczka na dwóch resorach i panowie Smyczkowscy

\footnotetext{
37 Ibidem, s. 154.
} 
[...] razem z niej wyskoczyli” (42); życie na kredyt chętnie udzielany przez Żydów pracujących dla prezesa Zagartowskiego zaowocowało staranniejszym wyglądem uprzęży - oto bowiem „półszorki pana Skrętskiego jaśniaty mosiadzami" (93).

Dostatek i elegancję domu matki Henryka Podziemskiego ilustrują barwy przypisane przedmiotom luksusowym, np. nożyk ze stoniowej kości, ksiqżeczki żólte, zielonkawe i niebieskie. Zamożność i zamiłowanie do porządku Szlomy podkreśla fotel obity czerwonym safianem, stojący obok kanapy obitej materia, szafy pełnej książek i biurka, jedyne ślady nieporządku pozostały „w kąciku tylko, gdzie przybite było mosiężne lawabo ${ }^{38} \mathrm{i}$ gdzie wisiał ręcznik, stał brudny cebrzyk" (120). Drobiazgi, którymi się otacza, także są czyste i zadbane, jak lśniqce nożyczki. Z kolei wystawność uczty wyprawionej przez prezesa dla oszukiwanych sąsiadów oddaje srebrny wazon, ,z którego sterczała okragława główka butelki z szampanem" (136).

Barwy w opisach przyrody charakteryzują okolicę, jak czarna ziemia (,,po czarnej i rozmiękłej ziemi błyszczały tu i ówdzie jeziorka", 5), ilustrując jednocześnie cechy zmieniających się pór roku, np.: „W takim stanie była piękna w innej porze okolica starokonstantynowskiego powiatu: żyzna, wzgórkowata, ozdobiona prześlicznymi laskami, które teraz nie zielenity się" (6); ,jak to się czasem zdarza w połowie oktobra, stońce zaświeciło jasno” (6); „Gdy przyszła wiosna, gdy się wszystko okryło zielonościq" (168), precyzują pory dnia, np.: „Toż ja całą noc oka nie zmrużę, bo ta bezecna muzyka nie ustanie do białego dnia" (135), ale też podkreślają stany duchowe bohaterów, np. Kamili, kiedy po mszy żałobnej „zdawało się jej, że słońce inaczej świeci” (166).

Światło. Piękna pogoda, jasność dnia i - choć nie nazwany wprost - błękit nieba (,Niebo jednakże było czyste”, 6; „stońce świeci tak jasno, że możemy pójść i piechotą", 7) sprzyjają spotkaniom bohaterów i ich sentymentalnemu uczuciu, które wkrótce autor zamieni w wielką miłość: „Stońce świeciło jasno, tym blaskiem melancholicznym, tak podobnym do ostatniego uśmiechu, którym oddalający się przyjaciel żegna przyjaciela lub odjeżdżający w daleką podróż syn żegna rodziców i krewnych stojących na ganku i przesyłających mu ostatnie pocałowanie" (6). Czyste niebo konotujące błękit, a więc barwę nacechowaną dodatnio ${ }^{39}$, oddaje wielkie i prawe uczucie łączące głównych bohaterów: „młodzi ludzie zostali prawie sami [...] pod czystym niebem, które ich serca widziało" (108). Zrozpaczona po stracie ukochanego i żyjąca w niezgodzie z ojcem Kamila siada pod drzewem, gdzie błękit nieba i łagod-

${ }^{38}$ Lawabo 'rodzaj miednicy z upustem do wody, używanym szczególnie do mycia rąk w zakrystji’, SW, t. 2, s. 696.

39 Por. P. Kowalski, op.cit., s. 226. 
ne światło księżyca (,patrzała w niebo jasne, błękitne, na gwiazdki migajace pomiędzy ruszającymi się z lekka listkami, na księżyc cichy, milczący, który przez gałęzie drzew zaglądał i na twarz jej rzucał łagodne światło", 128-129) przygotowuja ją do - ostatniego jej zdaniem - spotkania z Józefem, zaś cienie drzew chronią ich miłość: „Cienie dtugie od topoli padały na nieszczęśliwych” (130), ukrywając pożegnanie.

Barwy otoczenia harmonizują z uczuciami bohaterów, zmierzch i noc sygnalizują smutek i poczucie straty: „Księżyc już zachodził, ciemniało na dworze, a jeszcze ciemniej było w jego [Józefa - J.Ż.Ch.] duszy" (130), jasność domu i ciemność otaczającego go świata ilustrują wzburzenie i rozpacz Kamili, która wyrzeka się ukochanego, by ratować jego dziadka: „Okno było otwarte i oświecone, a panna Kamila stała w nim z załamanymi rękami, z podniesioną głową i patrzyła w ciemniejace coraz niebo" (130). Cienie matki konotujace śmierć i stratę ${ }^{40}$ przywołuje Kamila, gdy rezygnuje z miłości: ,i przysięgam na cienie mojej matki, że nie będę żoną pana Józefa Starzyckiego bez twojej woli i pozwolenia" (154).

Ponowne spotkanie - po naprawieniu przez Kamilę krzywd wyrządzonych przez ojca i wypełnieniu przez Józefa obowiązków - odbywa się pod czystym i błękitnym niebem, kiedy ,klony szumiały nad ich głowami, bzy rozkwitające błękitnymi kitami dotykały ich ramion" (169), gdzie błękit konotuje doskonałość i szczęście ${ }^{41}$.

Zieleń pól staje się kolorem nadziei, która towarzyszy ukradkowym spotkaniom Kamili i Józefa, stając się pretekstem do wyjazdów z domu: ,-- Dokąd pojedziesz? - Gdziekolwiek przez wieś, na pole, już się tak ładnie zieleni" (100), ale też zapowiedzią przyszłych spotkań: „Wkrótce pan Józef został sam jeden na drodze. Brzegi jej zielenity się" (108).

Barwy kreujące świat przedstawiony podkreślają jego realizm, zieleń oddaje wygląd pól na wiosnę: ,ale czyż nie możemy przedać naszego zboża na gruncie, kiedy się tak pięknie zieleni?” (107); „Droga już wówczas była sucha, brzegi jej zielenity się młoda murawa" (107), choć autor sięga również po metaforyczne określenia, np.: „laski na wzgórzach przywdziewały wiosenna odzież” (107), ,zboża ozime zaczęły zielonym puchem okrywać pole” (107).

Na kartach powieści pojawiają się zwierzęta, wśród nich koń nazywany od barwy sierści kasztankiem i kasztanem ${ }^{42}$, a także białonóżka, co waloryzuje piękno klaczy. O wiernym psie Józefa dowiadujemy się, że miał uszy kasztanowate.

${ }^{40}$ W. Kopaliński, Stownik symboli, s. 46-48.

${ }^{41}$ Por. R. Tokarski, Semantyka barw..., s. 139.

${ }^{42}$ Zob. A. Zaręba, Nazwy barw w dialektach i historii języka polskiego, Wrocław 1954, s. 23 i 109. 
W językowej kreacji świata przedstawionego w Kollokacji Korzeniowski z umiarem przywołuje kolory - są to barwy od bieli (w tym: biaty, blady, papierowy ${ }^{43}$, siwy, srebrny), przez żótty (w tym: paliowy, żótć i wyzłocony), czerwony (w tym: purpurowy, rumiany ${ }^{44}$ ), zielony, blękitny (w tym: niebieski, siny, ciemnobłękitny, granatowy), brazowy (w tym: cynamonowy ${ }^{45}$, blond $^{46}$, jasnomigdałowy ${ }^{47}$, kasztanowy $^{48}$, kasztanowaty, kolor cegły, rudy, śniady ${ }^{49}$ ), różowy ${ }^{50}$, pomarańczowy ${ }^{51}$, szary (popielaty ${ }^{52}$, jasnopopielaty) po czarny oraz nankinowy - będący określeniem tkaniny o barwie żółtawoczerwonej. Uzupełniają je nazwy określające światło i ciemność: jasność, iskrzacy lustr, ciemność, cień.

Józef Korzeniowski najczęściej używa obiegowych, upowszechnionych nazw, takich jak: biały, błękitny, czarny, zielony, pomarańczowy, które uzupełnia pośrednimi, np.: śniady, siwy, jasnomigdałowy, przywołuje również nazwy barw, odwołując się do desygnatów, które prototypowo są z nimi związane, np. kolor cegły. W powieści odnajdujemy również nazwy ogólnikowe, tj. kolor (np. włosy nieczystego koloru, żywe kolory Irydy, kolor materii), pstrokaty (karczmy), które nie precyzują barwy desygnatów, pozostawiając dookreślenie kolorystyczne wyobraźni czytelnika. Rzadziej Korzeniowski konkretyzuje barwę przez porównanie z desygnatem o specyficznej, niepowtarzalnej barwie, np. powój ma błękit paznokci w febrze. W Kollokacji pojawiają się też nazwy osób i zwierząt, które w swojej strukturze semantycznej ${ }^{53}$ konotują barwy, np.: blondyn, brunetka, kasztanek.

Uzupełnia je słownictwo światła i cienia, w tym formy werbalne i nominalne, jak: jaśniejaca pięknością, błyszczqce loki, włosy lśniq jak krucze skrzydła. Z kolei uczucia bohaterów powieści dynamizuje blask i przywołanie barw konotujących ogień, życie: oczy iskrza sie, pałaja ogniem, lico płonie.

${ }^{43}$ Papierowa twarz 'delikatna, mleczna', SW, t. 4, s. 46.

${ }^{44} \mathrm{~W}$ powieści ma rzeczownikową formę rumieniec.

${ }^{45}$ Cynamonowy 'brunatny, brązowy', SW, t. 1, s. 361. Por. M. Ampel-Rudolf, Z badań leksykalnych i składniowo-semantycznych języka polskiego, Rzeszów 1994, s. 146.

${ }^{46}$ R. Tokarski, Semantyka barw..., s. 200.

${ }^{47}$ Migdałowy 'koloru migdałów, żółtopiaskowy', SW, t. 2, s. 977.

${ }^{48} \mathrm{~W}$ powieści kolor ten precyzuje sierść konia, która zdaniem Zaręby mogła być brązowa lub czerwonawa. Por. A. Zaręba, op.cit., s. 23.

49 Śniady 'brudno-brunatny, smagławy, ciemnawy', SW, t. 6, s. 745. Por. R. Tokarski, Semantyka barw..., s. 196-203.

${ }^{50}$ Por. R. Tokarski, Semantyka barw..., s. 183-190.

${ }^{51}$ Por. ibidem, s. 193-196.

${ }_{52}$ Por. M. Ampel-Rudolf, op.cit., s. 124.

${ }^{53}$ Por. R. Tokarski, Znaczenie słowa i jego modyfikacje w tekście, Lublin 1987, s. 103-140. 
W powieści odnajdujemy zróżnicowanie odcieni barw przez wprowadzenie porównań z komponentem nazwy barwy - w kreacji postaci: zęby biate jak perly, usta jak korale; w kreacji uczuć: zaczerwienić sie jak piwonia, zaczerwienić się jak róża, blady jak ściana, twarz jak trup blada, zblednać jak trup, zblednać jak z grobu. Uzupełniaja je frazeologizmy: „W ten moment czarno na biatym. Chcę wiedzieć” (109), „Był to Mazur spod ciemnej gwiazdy, dawny kawalerzysta” (95), „gotowam dostać zapalenia płuc i czarnej melancholii" (48).

Z kolei metafory odnajdujemy w kreacji przyrody: wiosenna odzież, odzież wiosny, zielony puch, a także $\mathrm{w}$ innych warstwach kreacji świata przedstawionego, np.: ,ale zdarzały się czasem szczęśliwe chwile, krótkie i jasne jak

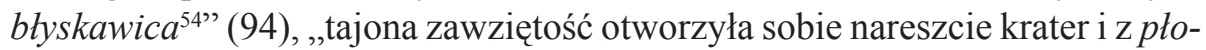
mieniami, dymem i lawq wyrzuciła się w powietrze” (142), „byłby prędko zginął, gdyby jej wzrok pełen życia i siły nie padł był a niego, jak ożywiający promień słońca na roślinę bliską zwiędnięcia” (68); „Niech mi piękne czytelniczki moje podziękuja, że im tej rozmowy nie powtarzam, słowa moje zepsułyby tę zlota tkanke, którą ich młodsza od mojej imaginacja, wymówniejsze, bo może w tejże chwili bijące serca na tym tle, którem im podał, wyhaftuje" (108).

Barwy użyte przez pisarza oddają realizm powieści, stąd pojawiające się nazwy kolorów w opisach przedmiotów i sytuacji, np.: „Pan Józef strzelił i w samym środku celu pokazał się punkt czarny i okragły” (111), Kamila „rysowała, ale niepoprawnie, ostro, bez pojęcia cieniów $i$ światta, bez uczucia piękności” (16).

\section{Podsumowanie}

W powieści Korzeniowskiego odnajdujemy barwy (białą, żółtą, czerwona, zieloną, błękitną, brązową, różową, pomarańczową, szarą i czarną), precyzujące wygląd bohaterów, ich siedzib oraz otaczającej je przyrody. Kolory w kreacji świata przedstawionego uzupełnia słownictwo światła i cienia, oddając nie tylko urodę bohaterów, ale przede wszystkim ich emocje i przeżycia.

Kolory mają wyróżnić żyjących ponad stan bohaterów - mieszkańców Czapliniec - spośród drobnej, ubogiej szlachty, a jednocześnie pokazać ich zły gust i brak smaku. Przeciwstawiona zostaje im tradycyjna rodzina Starzyckich, którzy także w ubiorze hołdują zasadom skromności i porządku, stąd barwy przypisane im i ich otoczeniu mają waloryzować cnoty, podkreślać zalety i te

${ }^{54}$ Jasny 'jaśniejący, świetny, światly, błyszczący', SW, t. 1, s. 142; błyskawica '1. blask poprzedzający grzmot, 2. blask, błysknięcie', SW, t. 2, s. 177. 
cechy charakteru, które autor uznaje za najważniejsze. Również w kreacji postaci głównej bohaterki Kamili Zagartowskiej i jej ojca prezesa nie ma wielu barw, a autor skromnie sięga jedynie do bieli i czerni, uzupełniając je słownictwem światła i cienia.

Kosztowne barwne drobiazgi oraz kolory w opisach przyrody podkreślają realizm miejsca akcji powieści.

Barwy w Kollokacji przywoływane są przede wszystkim w kreacji językowej bohaterów i ich uczuć, natomiast znacznie oszczędniej w opisach dworków i domów oraz natury, co podkreśla dominującą rolę postaci oraz podrzędną przyrody, opisów wsi i domów, będących tłem akcji.

\section{Jowita Żurawska-Chaszczewska}

\section{Stylistic function of colours in Józef Korzeniowski’s novel Kollokacja}

Korzeniowski's novel features different colours (white, yellow, red, green, skyblue (azure), brown, pink, orange, gray and black) that describe and specify the appearance of the protagonists, their places of abode and the surrounding nature. The significance of these "primary" colours are then complemented with a special vocabulary of light and shade that renders not only the beauty of the characters in the novel but chiefly their emotions and experience. The colours are to distinguish and differentiate the protagonists of the book, who are identifiable by coded references to colours. They are representatives of the local petty gentry, impecunious minor noblemen, who nevertheless live sumptuously and above their station and the colours are to show their bad taste and poor choices. This group is contrasted by a traditionally living family of the Starzyckis, who are faithful to their tradition and live a modest and orderly life, while their ideals concerning order and modesty can be seen even in their dress. Thus, the colours attributed to them and to their environment are to reevaluate virtues, highlight values and those traits of character that the author of the novel considered most important. Fanciful and colourful little things as well as the colours used in the descriptions of nature underline the realism of the setting in the novel. Colours in Kollokacja are mainly evoked in the linguistic creation of the protagonists and their emotions, whereas much more sparingly in descriptions of manors, houses and nature, which emphasizes even more the dominant role of the characters of the novel and the subordinate role of nature and the description of villages and cottages as the setting for the novel.

KEY WORDS: semantics, stylistics, colour.

dr Jowita Żurawska-Chaszczewska, Zakład Języka Polskiego Państwowej Wyższej Szkoły Zawodowej w Gorzowie Wielkopolskim; zainteresowania badawcze: badania diachroniczne i synchroniczne w zakresie słownictwa, stylistyka historyczna oraz idiolekt Józefa Korzeniowskiego. 